\title{
POTENSI OTEC DI PROVINSI PAPUA INDONESIA
}

\author{
Mahendra Widyartono ${ }^{1}$, Reza Rahmadian ${ }^{2}$ \\ ${ }^{1,2}$ Jurusan Teknik Elektro, Fakutas Teknik, Universitas Negeri Surabaya \\ ${ }^{1}$ mahendrawidyartono@unesa.ac.id \\ ${ }^{2}$ rezarahmadian@unesa.ac.id
}

\begin{abstract}
Abstrak -
Provinsi Papua merupakan salah satu provinsi terkaya di Indonesia dengan luas wilayahnya tiga kali lebih luas wilayah Pulau Jawa, namun kekayaan alam yang begitu besar belum dapat diolah karena belum adanya jaringan jalan yang memadai untuk menghubungkan wilayah-wilayah sentra produksi sehingga masih banyak wilayah-wilayah di Papua yang masi terisolasi dan kurang berkembang. Sama halnya dengan kondisi kelistrikan di Provinsi Papua, berdasarkan Statistik Ketenagalistrikan Tahun 2018 diketahui bahwa rasio elektrifikasi di Provinsi Papua sebesar 61,42 \% yang merupakan terendah kedua dari rasio elektrifikasi seluruh Indonesia. Permasalahan di atas hanya mungkin dapat diatasi dengan melakukan diversifikasi sumber energi baik menyangkut jenis maupun jumlahnya melalui pemanfaatan berbagai sumber energi alternative khususnya sumber energi terbarukan (renewable energy). Karena sistem OTEC dipasang di daerah pantai atau lepas pantai maka potensi OTEC di Provinsi Papua terdapat di daerah-daerah di sepanjang perairan Provinsi Papua yang memiliki kedalaman laut $\pm 1000 \mathrm{~m}$. Efisiensi maksimum sistem OTEC di perairan Nabire sebesar 0,76 sedangkan di perairan Biak, Bonggo, dan Jayapura mempunyai efisiensi maksimum yang hampir sama yaitu 0,84 .
\end{abstract}

Kata Kunci: OTEC, konversi energi.

\begin{abstract}
Papua Province is one of the richest provinces in Indonesia with an area of three times the area of Java, but the vast natural wealth cannot be processed because there is no adequate road network to connect the production centers so that there are still many areas in Papua is still isolated and underdeveloped. Similar to the electricity conditions in the Papua Province, based on the Electricity Statistics of 2018 it is known that the electrification ratio in Papua Province is 61.42\%, which is the second lowest of the electrification ratio of all of Indonesia. The above problems can only be overcome by diversifying energy sources both in terms of species and numbers through the use of various alternative energy sources, especially renewable energy sources. Because the OTEC system is installed on the coast or offshore, the potential of OTEC in the Papua Province is found in areas along the waters of the Papua Province which have a sea depth of $\pm 1000 \mathrm{~m}$. The maximum efficiency of the OTEC system in Nabire waters is $\mathbf{0 . 7 6}$ while in the waters of Biak, Bonggo and Jayapura the maximum efficiency is approximately equal to 0.84 .
\end{abstract}

Keywords: OTEC, energy conversion.

\section{PENDAHULUAN}

Papua adalah sebuah pulau yang terletak di sebelah utara Australia dan merupakan bagian dari wilayah timur Indonesia. Sebelum tahun 2004, provinsi Papua mencakup seluruh wilayah Papua Bagian Barat, namun sejak tahun 2004 dibagi menjadi dua provinsi dengan bagian timur tetap memakai nama Papua sedangkan bagian barat menggunakan nama Papua Barat. Provinsi Papua merupakan provinsi dengan luas terbesar yaitu kurang lebih $319.036,05 \mathrm{~km}^{2}$ dengan garis pantai 1.170 Km dan memiliki 556 pulau [1]. Provinsi Papua memiliki 28 Kabupaten dan 1 Kota, dengan Kabupaten Puncak Jaya merupakan yang tertinggi di pulau Papua, sedangkan yang terendah adalah Kota Merauke. Sebagai daerah tropis dan memiliki wilayah kepulauan, Pulau Papua memiliki kelembaban udara relatif tinggi yaitu berkisar antara 80-89\% dan kondisi geografis yang bervariasi mempengaruhi penyebaran penduduk yang tidak merata. Jumlah penduduk Provinsi Papua proyeksi pada tahun 2018 sebesar 3.322.526 jiwa dengan penduduk terbanyak terletak di Kabupaten Jayapura dengan jumlah 297.775 jiwa, Kabupaten Merauke dengan jumlah 225.714 jiwa, dan Kabupaten Mimika dengan jumlah 215.493 jiwa.

Provinsi Papua merupakan salah satu provinsi terkaya di Indonesia dengan luas wilayahnya tiga kali lebih luas wilayah Pulau Jawa, namun kekayaan alam yang begitu besar belum dapat diolah karena belum adanya jaringan jalan yang memadai untuk menghubungkan wilayah-wilayah sentra produksi sehingga masih banyak wilayah-wilayah di Papua yang masi terisolasi dan kurang berkembang. Sama halnya dengan kondisi kelistrikan di Provinsi Papua, berdasarkan Statistik 
Ketenagalistrikan Tahun 2018 diketahui bahwa rasio elektrifikasi di Provinsi Papua sebesar 61,42 \% yang merupakan terendah kedua dari rasio elektrifikasi seluruh Indonesia. Rasio elektrifikasi adalah perbandingan rumah tangga berlistrik dengan jumlah rumah tangga. Provinsi Papua memiliki 4.871 desa dengan jumlah desa yang sudah mendapatkan listrik sebesar 2.778 desa. Hal ini berarti baru $57,03 \%$ desa di Provinsi Papua yang sudah teraliri listrik dan masih banyak desa yang belum mendapatkan listrik [2]. Kapasitas terpasang pembangkit tenaga listrik PLN di Provinsi Papua pada tahun 2017 menurut Statistik Ketenagalistrikan Indonesia tahun 2018 adalah sebesar 218,06 MW. Permasalahan di atas hanya mungkin dapat diatasi dengan melakukan diversifikasi sumber energi baik menyangkut jenis maupun jumlahnya melalui pemanfaatan berbagai sumber energi alternative khususnya sumber energi terbarukan (renewable energy). Ocean Thermal Energy Conversion (OTEC) adalah salah satu metode sumber energi terbarukan yang berasal dari laut.

Sinar matahari yang jatuh di lautan begitu kuat diserap oleh air laut dengan efektif dan ditangkap di permukaan laut antara 35 meter sampai 100 meter. Di wilayah lautan tropis sekitar $15^{\circ}$ lintang utara dan $15^{\circ}$ lintang selatan, panas yang diserap matahari menghangatkan air permukaan ke nilai kurang lebih $28^{\circ} \mathrm{C}\left(82^{\circ} \mathrm{F}\right)$ yang hamper konstan siang dan malam dan dari bulan ke bulan. Suhu rata-rata tahunan permukaan air laut bervariasi dari sekitar $27^{\circ} \mathrm{C}$ hingga $29^{\circ} \mathrm{C}$.

Di bawah permukaan laut, air menjadi lebih dingin dengan meningkatkan kedalaman hingga 800 - 1000 m (2500 hingga 3300 kaki). Pada kedalaman tersebut suhu air laut menjadi $4,4^{\circ}$ $\mathrm{C}\left(40^{\circ} \mathrm{F}\right)$. Dibawah kedalaman $1000 \mathrm{~m}$ hingga $3650 \mathrm{~m}$ suhu air laut hanya turun beberapa derajat saja. Dengan demikian, terdapat reservoir air dingin yang besar berada di kedalaman 3000 kaki. Air dingin ini adalah akumulasi air es dari kutub yang mencair. Karena kepadatannya yang lebih tinggi dan pencampuran dengan air yang lebih hangat di atas, air dingin mengalir di sepanjang dasar laut, dari kutub ke arah garis khatulistiwa, menggantikan air dengan kerapatan yang lebih rendah di atas.

Hasil dari dua proses fisik ini adalah terbentuknya reservoir air hangat yang besar pada permukaan laut dan reservoir air dingin yang besar di dasar laut, dengan perbedaan suhu antara $22-25^{\circ} \mathrm{C}\left(40-45^{\circ} \mathrm{F}\right)$. Struktur ini ditemukan di seluruh area lautan tropis dimana kedalamannya melebihi 1000 m (3300 kaki). Perbedaan suhu dipertahankan sepanjang tahun, dengan variasi beberapa derajat celcius karena adanya efek musiman dan cuaca serta perubahan siang dan malam dalam satu hari.

Proses konversi energi laut ini (OTEC) menggunakan perbedaan suhu untuk mengoperasikan mesin panas (heat engine) yang akan menghasilkan listrik. Perhitungan menunjukkan bahwa OTEC yang dibangun pada lautan di daerah tropis dapat dioperasikan secara terus-menerus, tanpa ada dampak lingkungan, jika daya yang dihasilkan terbatas pada sekitar 0,5 MWe (bersih) per mil persegi permukaan air laut $\left(0,19 \mathrm{MWe} / \mathrm{Km}^{2}\right)$. Jumlah daya ini sesuai dengan konversi $0,07 \%$ dari rata-rata energi matahari yang diserap menjadi listrik [3].

Gambar dibawah merupakan peta yang menunjukkan perbedaan suhu di perairan tropis antara permukaan dan dasar laut (1000 m). Daerah yang paling cocok untuk operasi OTEC adalah daerah dengan perbedaan suhu $(\Delta \mathrm{T})$ melebihi $22^{\circ} \mathrm{C}\left(40^{\circ}\right.$ F).

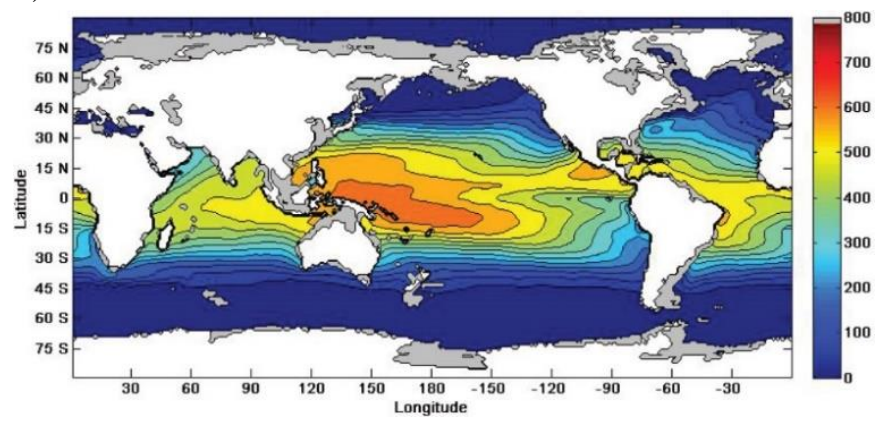

Gambar 1. Peta perbedaan suhu air laut sumber OTEC

\section{SISTEM OCEAN THERMAL ENERGY CONVERSION}

Sistem OTEC dapat dibagi menjadi dua kategori : siklus tertutup dan siklus terbuka. Pada siklus tertutup, fluida kerja dipertahankan ( dipompa kembali ke evaporator setelah proses kondensasi) seperti gambar 2. Pada sistem terbuka, fluida kerja dilepaskan setelah digunakan seperti gambar 3. Dalam sistem ini fluida kerjanya berupa uap air. Air laut hangat dipompa ke dalam ruang hampa dimana tekanan dikurangi dengan pompa vakum ke titik yang cukup rendah sehingga mengakibatkan air mendidih. Uap tekanan rendah tersebut kemudian dimasukkan ke turbin uap dan setelah keluar dari turbin uap didinginkan kembali dengan menggunakan air dingin untuk kemudian dibuang kembali ke laut.

Cara pendinginan uap yang melalui turbin uap tidak menggunakan kontak langsung dengan air dingin tetapi uap tersebut dimasukkan ke heat exchanger yang didinginkan dengan air laut dingin yang berasal dari dasar laut. Dalam hal ini, uap yang terkondensasi menjadi sumber air tawar. Sistem OTEC siklus terbuka masih dalam tahap penelitian dan pengembangan akan tetapi dapat memberikan performa yang lebih baik, terutama apabila ada produk lain yang dihasilkan selain listrik yaitu air tawar, dan air tersebut dapat dikemas sebagai produk yang dapat dijual ke masyarakat.

\section{Proses OTEC siklus tertutup}

Siklus tertutup OTEC menggunakan cairan ammonia sebagai fluida kerja. Skematik OTEC siklus tertutup dapat 
dilihat pada gambar 4. Air hangat dipompa dari permukaan air laut dan masuk ke boiler (evaporator) yang terdapat cairan ammonia didalamnya. Cairan ammonia kemudian mendidik menghasilkan uap dengan tekanan 9,3 atm (940 kPa). Uap tersebut kemudian masuk ke kondenser yang didinginkan oleh air dingin yang diambil dari dasar laut dengan kedalaman (1000 $\mathrm{m})$. Tekanan uap dari ammonia pada suhu di dalam kondenser adalah 6,1 atm $(620 \mathrm{kPa})$. Karena terjadi perbedaan tekanan yang cukup signifikan sehingga dapat menggerakkan turbin dan menghasilkan listrik.

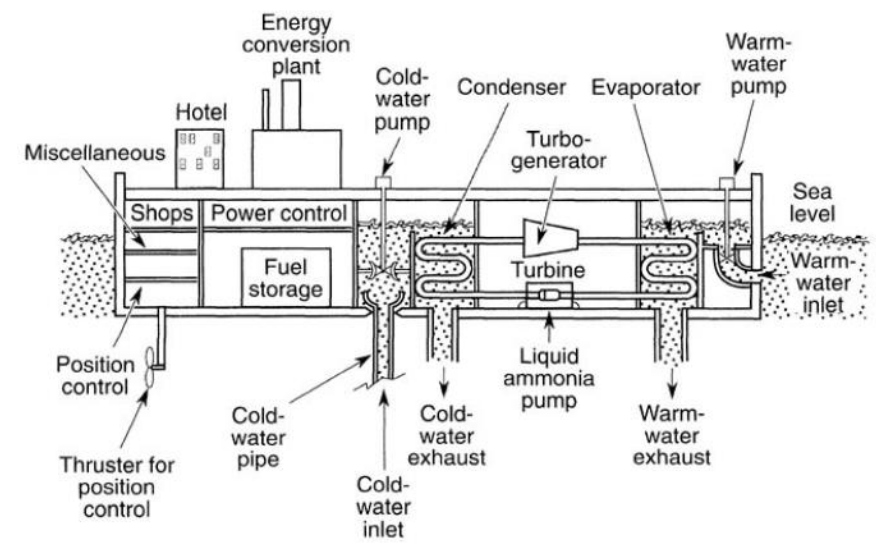

Gambar 2. Diagram sistem OTEC siklus tertutup

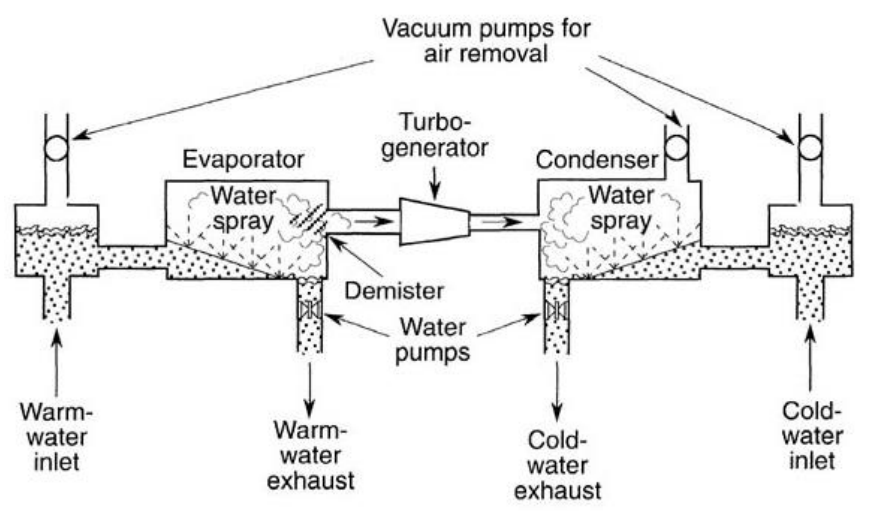

Gambar 3. Diagram sistem OTEC siklus terbuka

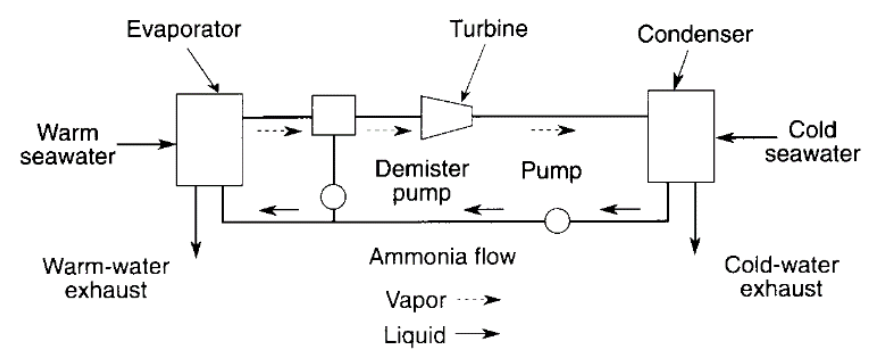

Gambar 4. Diagram alir siklus daya mesin panas OTEC pada umumnya
Ketika ammonia mengembun, cairan tersebut dipompa kembali ke evaporator untuk menyelesaikan siklusnya, membangkitkan listrik secara terus menerus selama air hangat dan air dingin terus mengalir.

\section{Efisiensi OTEC}

Ada limit teoritis terhadap efisiensi sistem OTEC dalam mengkonversi energi panas yang tersimpan pada permukaan air laut tropis menjadi energi mekanik. Sesuai dengan persamaan di bawah :

$$
\eta_{\max }=\frac{T_{W}-T_{C}}{T_{W}}
$$

Dimana $\eta_{\max }=$ efisiensi carnot, $\mathrm{T}_{\mathrm{W}}=$ suhu air hangat, $\mathrm{T}_{\mathrm{C}}=$ suhu air dingin.

Persamaan diatas mendefinisikan prinsip dari mesin carnot. Berdasarkan persamaan (1) diatas dapat disimpulkan bahwa idealnya efisiensi maksimum tergantung hanya dari suhu air dingin dan air panas. Oleh karena suhu air laut pada tiap musim bervariasi, hal ini dapat mempengaruhi daya yang dihasilkan dari sistem OTEC secara keseluruhan.

\section{POTENSI OTEC DI PROVINSI PAPUA}

OTEC merupakan salah satu energi alternative yang dapat digunakan di Provinsi Papua. Karena sistem OTEC dipasang di daerah pantai atau lepas pantai maka potensi OTEC di Provinsi Papua terdapat di daerah-daerah di sepanjang perairan Provinsi Papua yang memiliki kedalaman laut $\pm 1000 \mathrm{~m}$. Daerah tersebut berada di perairan utara dari Provinsi Papua yaitu Jayapura, Nabire, Biak, dan Bonggo. Daerah di perairan selatan Provinsi Papua tidak dapat digunakan untuk OTEC karena kedalamannya kurang dari $100 \mathrm{~m}$ sehingga perbedaan suhu antara air hangat di permukaan dan air dingin di kedalaman laut tidak begitu besar. Gambar 5 dan 6 merupakan profil kedalaman laut perairan dekat dengan kota Jayapura dan Biak Kota.

Tabel 1 menunjukkan rata-rata suhu permukaan air laut, suhu air laut dalam, dan efisiensi maksimum sistem OTEC di Nabire, Biak dan Bonggo. Gambar 7, 8, 9 dan 10 menunjukkan profil rata-rata suhu air laut di Nabire, Biak, Bonggo dan Jayapura.

Tabel 1. Rata-rata suhu air laut dan efisiensi

\begin{tabular}{lcccc}
\hline \multicolumn{1}{c}{ Kota } & $\mathbf{T}_{\text {hangat }}$ & $\mathbf{T}_{\text {dingin }}$ & $\boldsymbol{\Delta} \mathbf{T}$ & Efisiensi \\
\hline Nabire & 29.11 & 6.95 & 22.16 & 0.76125 \\
\hline Biak & 29.30 & 4.52 & 24.78 & 0.845734 \\
\hline Bonggo & 29.31 & 4.52 & 24.79 & 0.845786 \\
\hline Jayapura & 29.30 & 4.55 & 24.75 & 0.84471 \\
\hline
\end{tabular}


Di Nabire suhu dingin $\pm 6,95{ }^{\circ} \mathrm{C}$ karena kedalaman air lautnya $\pm 600 \mathrm{~m}$ sementara di Biak dan Bonggo kedalaman air laut mencapai > $1000 \mathrm{~m}$ dengan suhu air dingin pada kedalaman $1000 \mathrm{~m} \pm 4,52{ }^{\circ} \mathrm{C}$. Efisiensi maksimum sistem OTEC di perairan Nabire sebesar 0,76 sedangkan di perairan Biak, Bonggo, dan Jayapura mempunyai efisiensi maksimum yang hampir sama yaitu 0,84 .

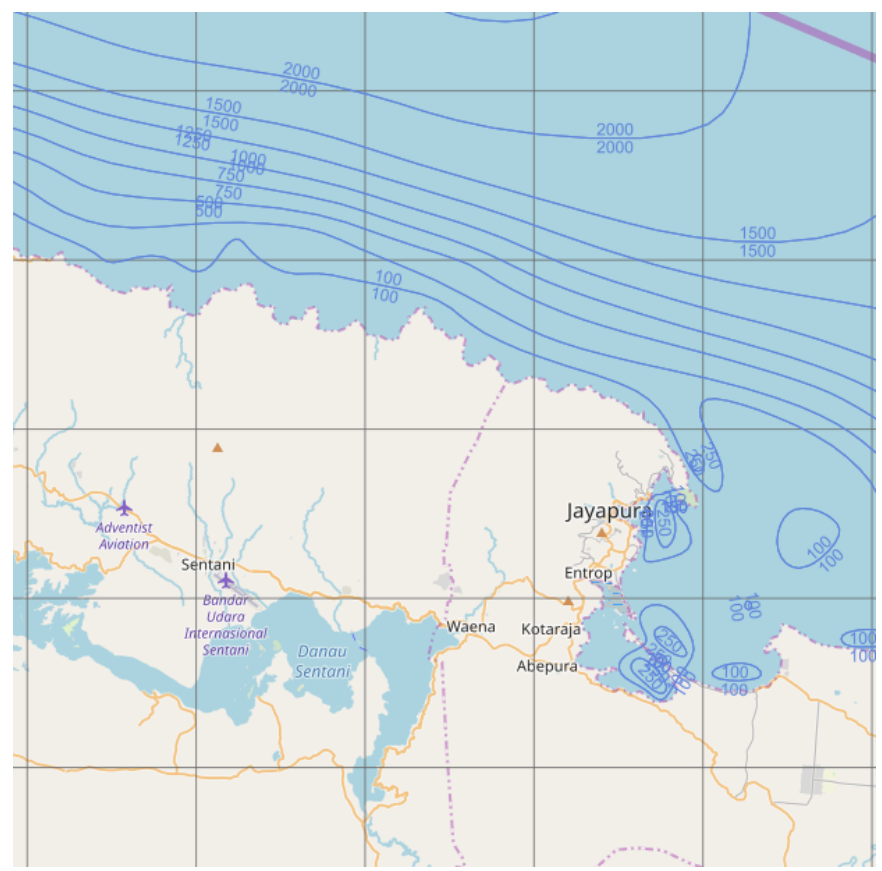

Gambar 5. Profil kedalaman laut perairan kota Jayapura

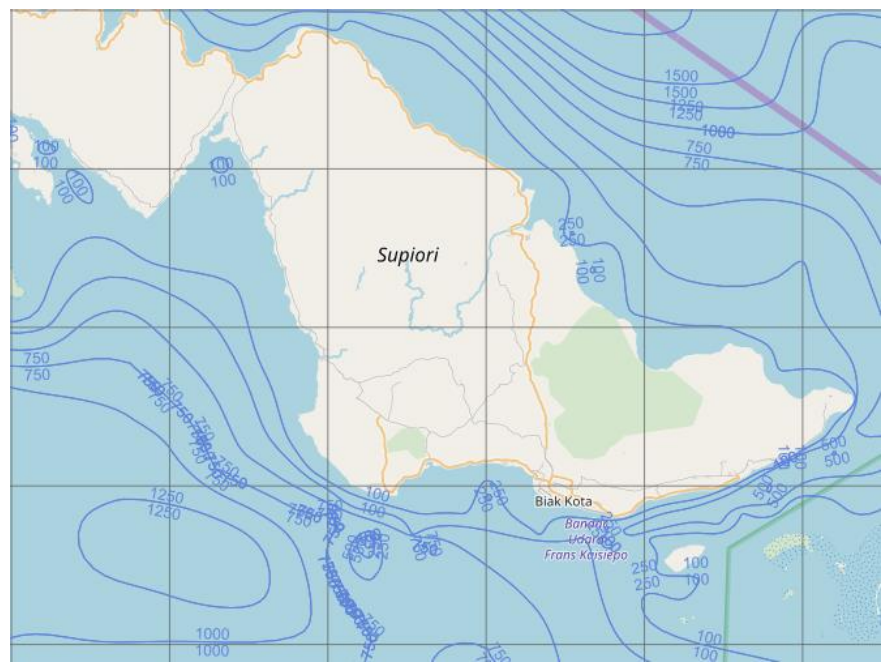

Gambar 6. Profil kedalaman laut perairan Biak Kota

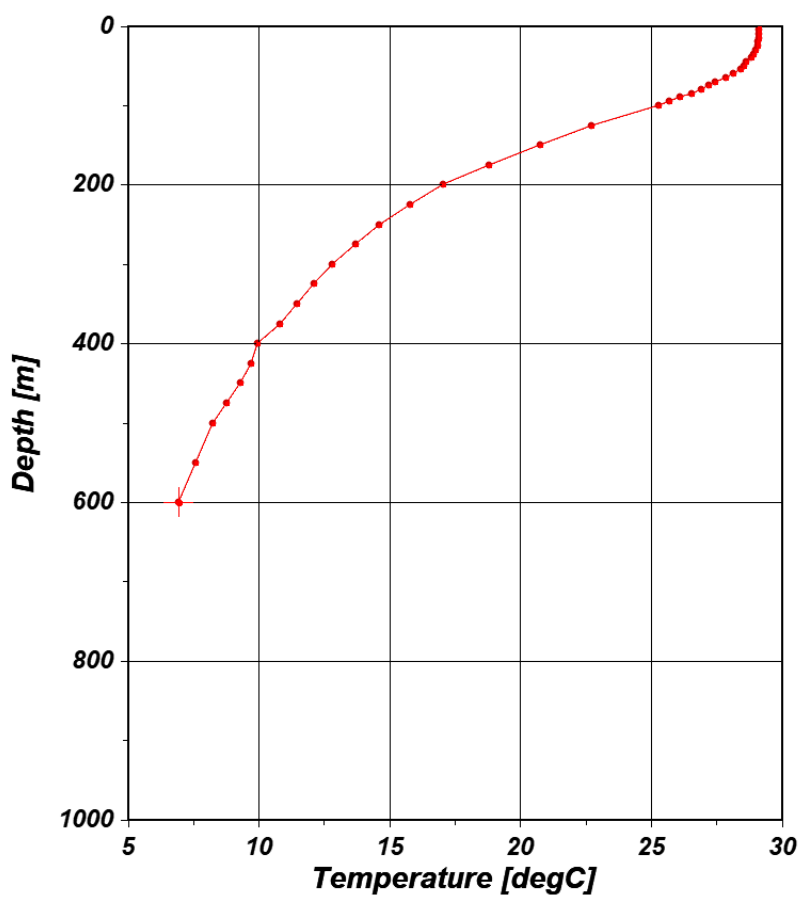

Gambar 7. Profil suhu rata-rata air laut di Nabire

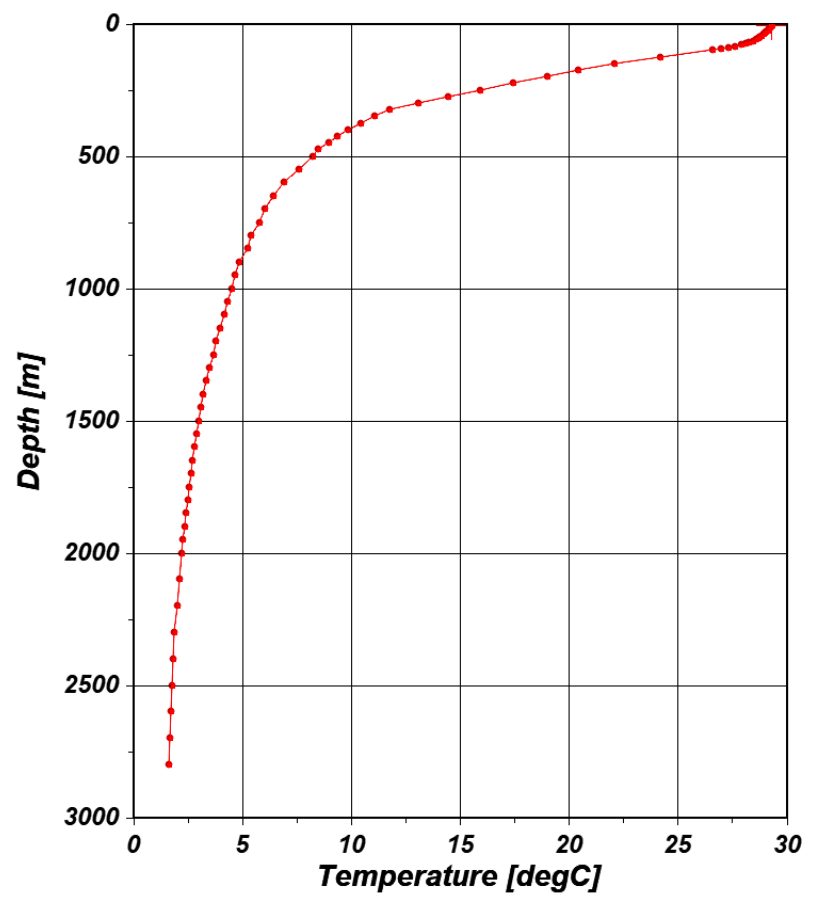

Gambar 8. Profil suhu rata-rata air laut di Biak 


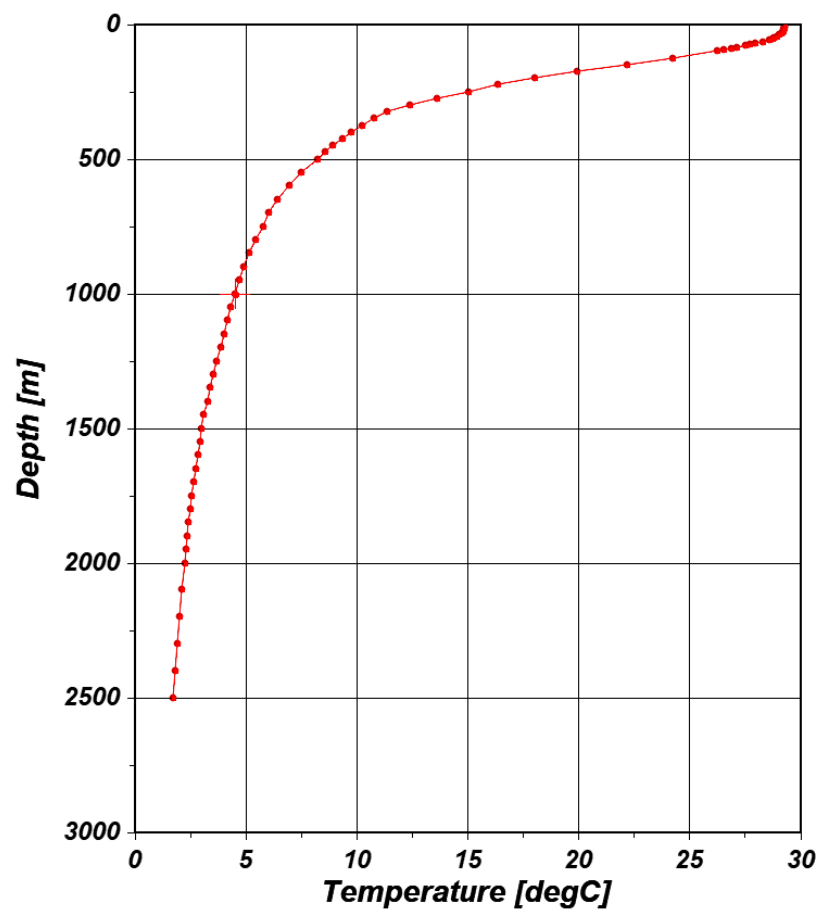

Gambar 9. Profil suhu rata-rata air laut di Bonggo

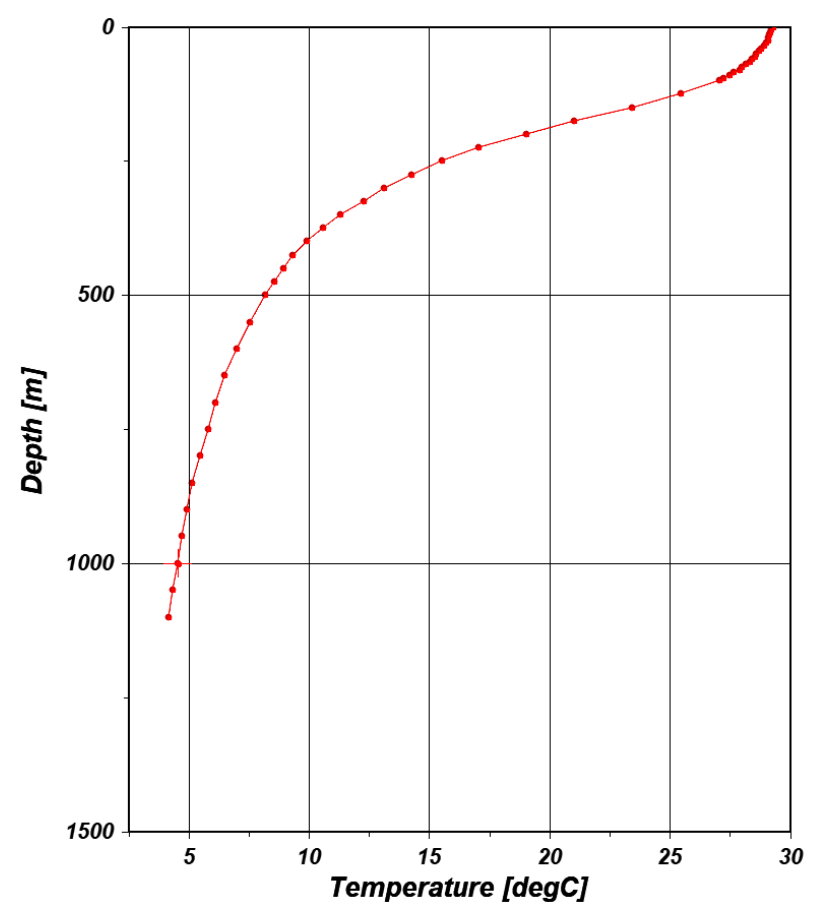

Gambar 10. Profil suhu rata-rata air laut di Jayapura

\section{PENUTUP}

\section{Simpulan}

Paper ini mendiskusikan potensi OTEC di Provinsi Papua, Indonesia, tepatnya di perairan Nabire, Biak, Bonggo dan Jayapura. Dapat disimpulkan bahwa potensi OTEC di Biak, Bonggo dan Jayapura mempunyai efisiensi yang kurang lebih sama yaitu 0,84. Efisiensi OTEC di Nabire lebih rendah yaitu 0,76 dikarenakan perairan di Nabire mempunyai kedalaman air laut kurang dari $1000 \mathrm{~m}$ akan tetapi masih mempunyai perbedaan suhu antara air hangat dan air dingin yang cukup besar sehingga masih bisa digunakan untuk sistem OTEC. Hasil ini diharapkan dapat membantu dalam perencanaan dan mengoptimalkan penggunaan OTEC di Indonesia khususnya Provinsi Papua.

\section{DAFTAR PUSTAKA}

[1] Badan Pusat Statistik 2018. "Statistical Yearbook of Indonesia 2018". BPS Statistik Indonesia. 2018.

[2] Triboesono, A. Statistik Ketenagalistrikan 2017. "Kementrian Energi dan Sumber Daya Mineral". 2018.

[3] Avery, W.H., dan Wu, C. "Renewable Energy from the Ocean : A Guide to OTEC". Oxford University Press. 1994.

[4] Khaligh A dan Onar C. "Energy, Power Electronics and Machine Series". CRC Press Taylor \& Francis Group.

[5] Koto J. "Potential of Ocean Thermal Energy Conversion Indonesia" Vol.4 No.1. International Journal of Environmental Research \& Clean Energy. 2016.

[6] Syamsudin, M.L. "Otec Potential in The Indonesian Seas". Energy Procedia 65 page 215-222. Conference and Exhibition Indonesia - New, Renewable Energy and Energy Conversation. 2015.

[7] Sinuhaji A R. "Potential Ocean Thermal Energy Conversion (OTEC) in Bali Vol.1 page 5-12. Renewable Energy and Energy Conversion Conference and Exhibition. 2015. 